\title{
APUNTES BIBLIOGRÁFICOS
}

\section{CUERPOS EMERGENTES Revelando una historiografía del arte feminista}

\author{
EMERGING BODIES \\ Revealing a Historiography of Feminist Art
}

Verónica Cinthia Fryga / veronicafryga@gmail.com

Facultad de Artes. Universidad Nacional de La Plata. Argentina

Reseña a Andrea Giunta (2018). Feminismo y arte latinoamericano. Historia de artistas que emanciparon el cuerpo. Ciudad Autónoma de Buenos Aires, Argentina: Siglo Veintiuno, 296 páginas

Recibido: 22/2/2020

Aceptado: $14 / 6 / 2020$

\section{RESUMEN}

Con el objetivo de transformar el sistema del arte y, con él, la sociedad Andrea Giunta revela en su última obra Feminismo y arte latinoamericano. Historia de artistas que emanciparon el cuerpo, cómo el feminismo se ha estado gestando en las producciones de los años sesenta y ochenta para emerger con fuerza en la actualidad. Se trata de un valioso aporte historiográfico, construido a partir de un corpus de obras que utilizan el cuerpo como soporte principal, desmontando estereotipos caducos e invitando a la reflexión.

\section{PALABRAS CLAVE}

Historiografía; cuerpo; resistencia; feminismo

\begin{abstract}
With the aim of transforming the art system and with it, society, Andrea Giunta reveals in her latest work, Feminism and Latin American art. History of artists who emancipated the body how feminism has been brewing in productions of the sixties and eighties to emerge strongly today. It is a valuable historiography contribution, built from a corpus of images that use the body as a support, dismantling outdated stereotypes and inviting reflection.
\end{abstract}

\section{KEYWORDS}

Historiography; body; resistance; feminism 
En junio de 2018, salió a la venta la primera edición de Feminismo y arte latinoamericano. Historia de artistas que emanciparon el cuerpo, de Andrea Giunta. El carácter innovador del libro reside en la puesta en valor de obras que contribuyeron a la construcción de un imaginario nuevo, despojado de estereotipos de género. La urgencia de traer al debate un tema como este ha sido desde siempre un interés de la autora, quien desde sus inicios en la profesión de historiadora, investigadora y docente se ha cuestionado sobre la situación desigual de la mujer en el mundo del arte.

En el primer capítulo, determina un posible origen de la historiografía del arte feminista en el artículo "Why have there been no great woman artists?» [¿Por qué no han existido grandes artistas mujeres?»] (1971), de Linda Nochlin. A partir de aquí, traslada el interrogante a la situación del arte argentino, y otorga legitimidad y peso a la causa por medio de estadísticas. Los resultados demuestran que, por un lado, la mayoría de los premiados han sido históricamente varones y, por otro lado, señala que hasta los años noventa no existía en la Argentina ningún material historiográfico que asumiese una perspectiva crítica de género. Esta situación la llevó a comprometerse con la difícil tarea de comenzar a generar material teórico desde una perspectiva propia:

La respuesta de un historiador del arte radica en investigar, analizar e interpretar el repertorio de obras que nos han sido vedadas sin dejar de interrogar; a su vez; las circunstancias que llevaron al estado de cosas. Ante la naturalización y el lugar común; las opciones son la problematización y la investigación (Giunta, 2018, p. 30).

En el segundo capítulo analiza comparativamente la obra pictórica de Clemencia Lucena (Colombia) y los films de militancia de María Luisa Bemberg (Argentina), estableciendo como elemento en común la construcción social de las sexualidades y la intervención de la política. $\mathrm{Si}$ bien encuentra en sus producciones tintes feministas, afirma que estos quedaron relegados a un segundo plano; por considerarse una política menor en función de otra mayor. La emergencia del movimiento feminista se vio, en su etapa prematura, disociada por las políticas internas de cada movimiento y por el contexto sociopolítico de los años sesenta y setenta. 
En el tercer capítulo, analiza el film Taller (1975), de la cineasta Narcisa Hirsch; se detiene sobre los objetos captados por la cámara - fotografías de niños, una cama, una mesa-, que pueden leerse como primeros indicios de la construcción del sujeto femenino, desde una perspectiva crítica. Giunta no se arriesga todavía a hablar de un arte feminista, pero sí encuentra en esta obra un primer esbozo del mismo. A su vez, establece un paralelismo entre el cine experimental, el cine político y la formación de la segunda ola del feminismo en la Argentina.

En el cuarto capítulo, aborda la emergencia del feminismo en México, a partir de la selección de un corpus de obras que van desde el collage hasta la performance, exponiendo como el cuerpo surgía como problema y trasgresión; e indaga, además, sobre la relación entre lo femenino, el feminismo y el arte.

En el quinto capítulo, piensa la instalación Sal-si-puedes (1983), de Nelbia Romero (Uruguay), en el contexto de la última dictadura cívico militar. El título alude a la emboscada y a la consecuente masacre contra los charrúas durante el proceso de consolidación de la nación uruguaya; hecho que interpreta como el primer acto de terrorismo de Estado y a los charrúas como los primeros desaparecidos. La obra produce un efecto historicista, pues alude al presente a través de un acontecimiento del pasado.

Finalmente, el sexto capítulo, "Sentir pese a todo", siembra esperanzas al afirmar que frente a la cultura del miedo ha sabido aflorar una cultura de la resistencia; y esta se manifiesta en la obra de la fotógrafa Paz Errázuriz (Chile). Sus imágenes muestran más de lo que aparentan, funden lo histórico con lo emocional. La serie Dormidos (1979-1980) retrata una sociedad paralizada por el terror implantado. El juego de imágenes que utiliza se deduce por asociación: observamos transeúntes junto a un perro que yace dormido; el mensaje aparece enmascarado y es el espectador quien, a modo de cómplice, debe develarlo.

Además, muestra la otredad en la piel de Ixs travestis retratados en la serie La manzana de Adán (1984-1990) y de los internos de un hospital psiquiátrico recopilados en el libro El infarto del alma (1994). Los títulos que coloca llevan a reflexionar sobre el olvido, la marginalidad, la destrucción total o parcial del cuerpo expuesto a situaciones precarias y 
hostiles. ¿Cuándo un alma se infarta y muere? ¿Cuándo la sociedad ha decidido olvidarla y subyugarla; cuando la mirada del que observa es neutral e ingenua, carente de empatía y de humanidad?

Al pensar en conjunto todas estas obras, notaremos que decantan un proceso de construcción de la identidad y de lo femenino, a partir del uso de una iconografía nueva desarrollada en torno al cuerpo, que se deconstruye y adquiere poder transformador; pero sin olvidar que ha sido objeto de abuso, de violencia y de tortura. Las obras se entrelazan para desembocar finalmente en el activismo político de la mano del movimiento feminista actual, al cual la autora adhiere y participa de forma activa.

A modo de cierre, el libro invita a familiarizarse con los nuevos términos creados por el feminismo; amplía de esta manera el campo de acción, no solo al ámbito del arte, sino también a la esfera social al abordar temas de etnia y de clase. Giunta dispone un marco teórico posible y exige una continua reformulación del mismo, en el seno de una sociedad que, pese a todo el cambio sociopolítico, persiste en privilegiar el trabajo de artistas que se ajustan a categorías seguras. El sistema del arte es, en parte, inamovible, sexista y heteronormativo, pero enseguida se resquebraja cuando surgen contradicciones de esta magnitud.

\section{REFERENCIAS}

Giunta, A. (2018). Feminismo y arte latinoamericano. Historia de artistas que emanciparon el cuerpo. Ciudad Autónoma de Buenos Aires, Argentina: Siglo Veintiuno.

Nochlin, L. (1971). Why Have There Been No Great Women Artists? [¿Por qué no han existido grandes artistas mujeres?]. ARTnews, (69). 